\title{
Bioactivity Analysis and Citral Content Estimation of Value Added Paneer Incorporated with Lemongrass Extract and Lemongrass Oil
}

\author{
Krupa Joseph $^{1 *}$, K. Jayaraj Rao ${ }^{1}$ and M. Vasundhara ${ }^{2}$ \\ D.T. Section, NDRI (SRS), Adugodi, Bengaluru - 560 030, India \\ Department of Horticulture, UAS (B), GKVK, Bengaluru-560065, India \\ *Corresponding author
}

\begin{tabular}{l} 
Ke y w o r d s \\
Paneer, \\
Lemongrass, Anti- \\
oxidant, Bioactivity, \\
Citral, Lemongrass \\
oil \\
\hline Article Info \\
$\begin{array}{l}\text { Accepted: } \\
\text { 04 May } 2019 \\
\text { Available Online: } \\
\text { 10 June } 2019\end{array}$ \\
\hline
\end{tabular}

Keywords

Paneer, Citral, Lemongrass oil

Article Info

04 May 2019

10 June 2019

\section{A B S T R A C T}

Effect of lemongrass extract and oil on the bioactivity (antioxidant and antimicrobial property) and citral content of paneer was evaluated in this study. Lemongrass was incorporated in the following three ways: i) cut and crushed leaves were added to milk @ $0,2,4$ and 6\% (w/v) or to coagulant solution @ 20\% (w/v) and extracted by heat treatment; ii) cut leaves were heat extracted in potable water followed by heat concentration, and chilling. The chilled water was used for soaking paneer blocks; iii) Lemongrass oil added to milk at $0,0.015,0.02$ and $0.025 \%$ levels. The studies on antioxidant characteristics as evaluated by DPPH and FC assays revealed that, RSA activity was the highest for paneer added with lemongrass oil (8.77\% inhibition) and the total phenolic compounds were found to be the maximum $(0.0056 \mathrm{mg} / \mathrm{g} \mathrm{GAE})$ for paneer incorporated with crushed lemongrass leaf. The antibacterial studies of paneer samples revealed that the incorporation of lemongrass extract as well as oil did not impart any antibacterial effect. Paneer sample with the addition of lemongrass leaf-bits ( $4 \% \mathrm{w} / \mathrm{v})$ into milk, was selected as the optimized sample based on organoleptic tests. In the gas chromatographic analysis, both isomers of citral, neral and geranial, were eluted out. It is concluded from the study, that lemongrass has fortified paneer with bioactive properties than control paneer and is a quite promising herb for the development of value added dairy products.

\section{Introduction}

Paneer represents a variety of Indian soft cheese, a base material for the preparation of a wide range of culinary dishes. It is highly nutritious and wholesome. Paneer consists of protein and usually all the fat, insoluble salts and colloidal materials, together with part of the moisture serum of the original milk, lactose, whey proteins, soluble salts, vitamins and other milk components (Kanawjia et al., 1990). In recent years, consistent efforts have been made to create flavoured paneer with novel additives viz., herbs and spices.

In food processing, herbs and spices have traditionally been incorporated to extend shelf life. Crude extracts of herbs and spices, and 
other plant materials rich in phenolics are being viewed with increasing interest in the food industry as they retard oxidative degradation of lipids and thereby improve the quality and nutritional value of food. Essential oils and their components are becoming popular as naturally occurring antimicrobial agents (Walker, 1994). The Food and Drug Administration (USA) considers most of the essential oils as GRAS (Generally Recognized As Safe). Many plant-derived antimicrobial compounds have a wide spectrum of activity against bacteria, fungi and mycobacteria and this has led to their usage as natural preservatives in foods (Faraget al., 1989; Conner and Beuchat, 1984; Jagannath, 2012).

Lemongrass is an aromatic perennial tall grass and a native herb from India, with rhizomes and densely tufted fibrous root, termed by our ancients as a "sacred herb" that is widely used as an essential ingredient in Asian cuisines because of its sharp lemon flavour. Botanically, lemongrass belongs to Family: Poaceae (Gramineae) and species, Cymbopogon. There are two main species, East Indian, Cymbopogon flexuosus and West Indian, Cymbopogon citratus. It is an economically important plant that has been used for centuries as a medicine because of its wide-ranging therapeutic properties (Fenwick et al., 1990).

Lemongrass contains an aldehyde namely citral, chemically known as 3,7-dimethyl-2,6octadienal (mixture of two geometric isomers, geranial (citral A) and neral (citral B)) as its major component in a 70-85\% concentration, which is responsible for the citrus aroma. Geranial and neral are light oily liquids. Geranial has a strong lemon odour while the lemon odour of neral is weaker but sweeter than geranial. Lemongrass also contains a volatile oil whose yield is about $0.5 \%$ from fresh grass $(1-2 \%$ essential oil on a dry basis), characterized by its yellow or amber colour and lemon-like odour (also possesses an herbaceous verbena-like odour not possessed by lemon oil). Other major phytochemicals are borneol (5\%), geraniol (2.6-40\%), geranyl acetate $(0.1-3 \%)$, linalool (1.2-3.4\%) and nerol (0.84.5\%) (Schaneberg and Khan, 2002; Carlson et al., 2001). The bioactive compounds from lemongrass are extracted by different methods such as boiling of oven dried leaves (decoction), boiling of freshly ground leaves (infusion) and steam distillation (essential oil).

Citral possesses antioxidant activity, and it may serve as one of the antioxidant defences of the plant against harmful free-radicals or reactive oxygen species. In other studies, citral was demonstrated to serve as a plant defence against the damaging effects of microorganisms. According to studies by Vazquez- Briones et al, (2015), the essential oil of Cymbopogon citratus exhibited high citral concentration with high phenolic content (149.20 mg GAE per 100ml) and antioxidant capacity $(44.06 \mathrm{mg}$ Trolox per $100 \mathrm{ml}$ of essential oil). Lemongrass has high antioxidant capacity and the free radical scavenging effect of hydro-alcoholic extract of Cymbopogon citratus was established (Rao et al., 2009).The comparative analysis of the antioxidant activities of methanolic and aqueous extracts of few selected herbs also proved the antioxidative potential of lemongrass leaves (Deepa Garg et al., 2012). Ethanol extract of lemongrass leaves has a potential as antioxidant because of its inhibitory activity against free radical DPPH (2, 2-diphenyl-1-picrylhydrazyl) (Hasim et al., 2015).

It has been established that lemongrass possesses antibacterial (Morris, et al., 1979; Dube et al., 1984; Onawunmi et al., 1984; Onawunmi et al., 1985; Elson and Underbakve, 1989; Ibrahim, 1992), antifungal 
(Josper and Liguari, 1958; Rao and Narasimh, 1971), nematocidal (Sangwan, et al., 1985), insect repellent (Jiang, 1993), antioxidant, antipyretic, anti thrombiotic and serum cholestrol lowering properties (Burger, et al., 1986; Elson and Underbakve, 1989). Lemongrass oil possesses bactericidal and anti-fungal properties, comparable to penicillin in its effectiveness (Lutterodt et al., 1999). Isam et al., (2009) studied the antimicrobial activity of lemongrass leaf extracts and demonstrated a broad-spectrum of activity against both gram-positive and gram negative bacteria and fungi, possibly the acidic nature of the extracts $(\mathrm{pH}$ values ranging between 3-5) combined with bioactive components (saponins, tannins, alkaloids and flavonoids) enhanced the antimicrobial activity of the extracts especially against the bacteria. Gram positive organisms were found more sensitive to lemongrass oil as compared to gram negative organisms.

Citral showed potent antifungal activity against various fungi which cause severe postharvest diseases in fruits (Ben-Yehoshua et al., 1995; Garcia et al., 2008). Saponins, tannins, alkaloids and flavonoids are present in lemongrass extracts and are known to be bactericidal, pesticidal or fungicidal in nature thus conferring the antimicrobial property to plant (Rios et al., 2005). Lemongrass oil and citral have a potent in vitro activity against Candida spp. (C. albicans, C. glabrata, $C$. krusei, $C$. parapsilosis and $C$. tropicalis) (Silva et al., 2008). Among different essential oils, cinnamon, lemongrass, Japanese mint, ginger grass, geranium and clove oils were observed as most promising against $C$. albicans. Citral showed in vitro antifungal potential against strains of $C$. albicans (Leite et al., 1986).

Herb extracts are known to preserve the quality of soybean oil, beef, meat, poultry, fish and lard. However, fortification by herbal extracts in dairy products would enhance the functionality of the product base, thus striving and aligning with the trend of increased consumption of natural remedies. Indian dairy industry should find ways to induce or to improve the functionality in traditional dairy products. Work reported about the study of bioactive properties of dairy products incorporated with lemongrass is meagre. Therefore, the present investigation was carried out to study the effect of incorporation fresh leaf extract of lemongrass as well as oil on bioactivities of the treated paneer.

\section{Materials and Methods}

For the preparation of paneer, fresh cow milk was procured from cattle yard of Southern Regional Station of National Dairy Research Institute, Bengaluru, filtered and standardized to $3.0 \%$ fat and $8.5 \%$ SNF. Fresh leaves medium sized, matured and dark green coloured- of lemongrass (Cymbopogon flexosus) grown in the Institute campus was picked up for the project work. Freshly extracted lemongrass oil was obtained from the Horticultural Section, University of Agricultural Sciences, GKVK, Bengaluru.

\section{Preparation of paneer}

Paneer was prepared in the laboratory as per Bhattacharya et al., (1971) with slight modification. Milk, standardized to $3.0 \%$ fat and $8.5 \% \mathrm{SNF}$ was heated to $90^{\circ} \mathrm{C}$ without holding, cooled to $80{ }^{\circ} \mathrm{C}$ and coagulated by the addition of $2 \%$ citric acid solution at $80^{\circ} \mathrm{C}$. The citric acid was added slowly to milk with continuous agitation till clear whey separated out. The curd was allowed to settle for $5 \mathrm{~min}$ and the whey was drained out by hanging the coagulum in muslin cloth. The curd was then collected and filled in wooden hoop lined with clean muslin cloth. Pressure was applied on the hooped curd @ 0.069 
$\mathrm{kg} / \mathrm{cm}^{2}$ for $20-25$ minutes. The paneer block was taken out from the hoop and then cooled by immersing in chilled water $\left(4\right.$ to $\left.6{ }^{\circ} \mathrm{C}\right)$ for $2 \mathrm{~h}$ for texturization. The paneer block was removed from chilled water and placed on wooden planks for 15 minutes for allowing the water to drain out. The paneer block was cut into $2 \mathrm{~cm}$ cubes and packed in LDPE pouches and stored in refrigerator $\left(7 \pm 2^{\circ} \mathrm{C}\right)$ for further analyses.

\section{Incorporation of lemongrass}

Lemongrass was incorporated into paneer by the following methods:

(1) Fresh lemongrass leaves were washed, and added in both cut form (3-5 cm long cuts) and crushed form (cuts were crushed in a mixer) and added to milk @ 0 (control),2, 4 and 6\% by the weight of milk before heat treatment.

(2) Fresh lemongrass oil was added to milk @ 0 (control), $0.015,0.020$ and $0.025 \%(\mathrm{v} / \mathrm{v})$ before heat treatment of milk.

(3) Extract from washed and cleaned lemongrass leaves (in crushed form) obtained by boiling the leaves in water (@ 10\% by volume of water) was concentrated to half the volume, followed by cooling, chilling and was then used as dipping water for paneer.

Optimal levels of the ingredients used during standardisation of the process for preparation of lemongrass flavoured paneer were determined using sensory evaluation as given in the Table 1

In the addition of lemongrass oil into milk, $0.015 \%$ addition was selected, based on optimum sensory scores. Level of addition of $4 \%(\mathrm{w} / \mathrm{v})$ was selected as the optimized sample for cut form and $2 \%(\mathrm{w} / \mathrm{v})$ addition for crushed samples. For the method of dipping coagulum in concentrated and chilled lemongrass extract, the cut form was found to be good.
The optimized lemongrass flavoured paneer ( $4 \% \mathrm{w} / \mathrm{v}$ addition in milk) had a proximate composition as follows: Total solids 44.74\%; Fat $-19.38 \%$; Protein - $21.25 \%$; Lactose $-2.47 \%$ and Ash - 1.64\%, which was found to be well within those reported in the literature.

The paneer samples are abbreviated as follows:

C: Control paneer; T1: Lemongrass extraction in milk (cut); T2: Lemongrass extraction in milk (crushed); T3: Dipping in lemongrass extract; T4: Lemongrass oil in milk

\section{Bioactivity analysis}

Antioxidant activity was measured using DPPH (2, 2-diphenyl-2-picryl hydrazyl) dye, as per the procedure described by (Shimada $e t$ al., 1992). The amount of total phenolics in paneer samples was determined with the Folin-Ciocalteu reagent according to the method of Singleton et al., (1999). Gas chromatographic analysis of paneer samples were performed as that reported by Aniruddha et al., (2011).

\section{Antimicrobial activity of lemongrass extracts and flavoured paneer}

\section{Test microorganisms used in the study}

Bacterial strain Escherichia coli (MTCC 1698), Staphylococcus aureus (MTCC7443) and Candida albicans (MTCC 7315) were procured from MTCC, Chandigarh.

\section{Inoculum preparation}

24 hour old pure cultures of E. coli and $S$. aureus were used for the preparation of bacterial suspension as per Mac-Farland Nephelometer Standard. Suspensions of organisms were made in sterile isotonic 
solution of sodium chloride $(0.9 \%$ w/v $) .0 .5$ McFarland standards $\left(1.5 \times 10^{8} \mathrm{CFU} / \mathrm{ml}\right)$ were used as a reference to adjust the turbidity of microbial suspension (Singh and Jain, 2011).

\section{Method of screening}

Sterilization of media, peptone water, distilled water, petri-plates, L-shaped glass rod, microtips were carried out in an autoclave at $121^{\circ} \mathrm{C}$ for $15 \mathrm{~min}$. The sterilized Nutrient agar was poured into each petri-dish and allowed to solidify under aseptic conditions inside the Laminar Air Flow (LAF) chamber in a ClassII biosafety cabinet. Sterile paper disc of $6 \mathrm{~mm}$ diameter was aseptically saturated with $30 \mu \mathrm{l}$ of the fresh lemongrass extract and dilute suspensions of the paneer samples(control paneer sample, lemongrass flavoured paneer with lemongrass leaves added in cut and crushed form and lemongrass oil added paneer) in 3 dilutions- $10^{1}, 10^{2}, 10^{3}$ respectively. These discs, were allowed to dry for 1hour in Laminar Air Flow (LAF) chamber for complete absorption of the sample and later placed onto solidified nutrient agar [Hi Media (M002)] surface swabbed with $30 \mu 1$ of respective test organism ( $1.5 \times 10^{8} \mathrm{CFU} / \mathrm{ml}$ using 0.5 McFarland's standard)with the help of a sterilized forceps. The plates were incubated for 24 hours at $37^{\circ} \mathrm{C}$. The results were recorded as three independent observations by measuring the zone of growth inhibition $(\mathrm{mm})$ around the disc.

\section{Statistical analysis}

In order to select the method of incorporation of lemongrass, 3 replications were conducted for each trial. The values of each attribute under study were subjected to statistical analysis by one way ANOVA using SPSS Software 16.0. The significance of treatments effect was determined by Tukey test at 5\% level of significance.

\section{Results and Discussion}

\section{Optimization of the process of manufacture of lemongrass flavoured paneer}

From various methods of incorporation of lemongrass, one sample has been selected based on sensory scores. When lemongrass was extracted into milk in cut form, $4 \%(\mathrm{w} / \mathrm{v})$ addition was found to be having the best score, whereas in crushed form, $2 \%(\mathrm{w} / \mathrm{v})$ addition was seen to be optimum.

Lemongrass when extracted into citric acid solution, the crushed form of addition obtained higher sensory scores than cut form, whereas for the method of dipping coagulum in concentrated and chilled lemongrass extract, the cut form was found to be good. In the addition of lemongrass oil into milk, $0.015 \%$ addition was selected based on optimum sensory scores, while for addition of oil into citric acid solution the effect of lemongrass oil on the sensory parameters of paneer were insignificant and hence the sample was not taken forward during further studies.

All the selected samples from each method of incorporation, was subjected to sensory evaluation by a panel of judges and the scores are tabulated in Table 1.

It is evident from the figures for sensory scores in the Table 1, that the extraction of cut lemongrass leaf in milk, obtained the highest score compared to all other samples, for most of the sensory parameters, including colour and appearance, flavour and overall acceptability, and the scores were statistically significant and comparable to that of control paneer sample.

Hence, the addition of cut lemongrass leaf $(4 \% \mathrm{w} / \mathrm{v}$ addition) into milk was selected as the optimized solution for the preparation of lemongrass flavoured paneer. 
Study of anti-oxidant properties of lemongrass flavoured paneer

Antioxidants are an important group of food additives that have the ability to protect against undesirable change of oxidizable nutrients and consequently extend shelf-life of foods. Antioxidants are receiving remarkable attention in the literature recently, due to their ability to preserve foodstuffs by retarding deterioration, rancidity and/or discolouration caused by oxidation. Plants are very good sources of natural antioxidants. These antioxidants are mostly produced via the secondary metabolism of plants and are referred to as secondary metabolites.

The results of radical scavenging activity (\% RSA) of lemongrass extract as well as samples of paneer incorporated with lemongrass, expressed as \% inhibition are presented in Table 2. In comparison to pure lemongrass extract with an RSA value of $72.62 \%$ inhibition, the RSA was found to be the highest for paneer added with lemongrass oil $(8.77 \%$ inhibition) among all the experimental samples and the activity was found to be the least for paneer dipped in lemongrass extract (3.53\% inhibition).

The results are in accordance with the findings reported in literature. Aqueous extracts of lemongrass were also found to inhibit oxidative stress particularly lipid peroxidation, as well as alteration of lipid membrane systems, caused by paracetamol (Ojo et al., 2006). A study conducted byRao et al., (2009) revealed that the extract of lemongrass at a concentration of $60 \mu \mathrm{g} / \mathrm{ml}$ resulted in a significant scavenging ability of 2,2-diphenyl-2-picryl hydrazyl (DPPH) (85\%) and concluded that lemongrass has high antioxidant capacity; Deepa Garg et al.,(2012) carried out a comparative analysis of the antioxidant activities of methanolic and aqueous extracts of the selected leaves of herbs commonly used in Indian cuisine (lemongrass, mint, coriander and curry leaves) adopting various assays including DPPH assay. Among the herbs investigated, lemongrass exhibited the maximum content of phenols, leading to a more powerful radical scavenging effect and hence greatest antioxidant profile. According to Villalobos (2015), it has been observed during preliminary experiments of antioxidant that extracts of fresh and dried lemongrass plant samples possess antioxidant activity against ascorbic acid, which is a widely-used standard. Hence, in the present study, we could observe that the lemongrass extract is conferred highly with antioxidant activity and this property got transferred to paneer in small amounts, when added with lemongrass extract and oil.

\section{Study of anti-oxidant properties of lemongrass flavoured paneer}

Total phenolic constituents of pure lemongrass extract as well as paneer samples added with lemongrass were determined by experimental method involving FolinCiocalteu reagent (Singleton et al., 1999). The range of phenolic content of all the samples expressed as mg/g Gallic Acid Equivalents (GAE) is presented in Table 3. It was found that the amount of phenolic compounds was high in the aqueous extract of lemongrass (1.7 $\mathrm{mg} / \mathrm{g}$ GAE). The paneer samples also exhibited positive results with the highest amount obtained for paneer incorporated with lemongrass leaf in crushed form $(0.0056 \mathrm{mg} / \mathrm{g}$ GAE), followed by paneer added with cut lemongrass leaf extract $(0.0046 \mathrm{mg} / \mathrm{g}$ GAE) and paneer with lemongrass oil in milk (0.004 $\mathrm{mg} / \mathrm{g}$ GAE) and the lowest concentration of $0.0037 \mathrm{mg} / \mathrm{g}$ GAE was obtained for paneer added with lemongrass oil. It is evident from the statistical analysis, that there was significant difference between the experimental samples $(\mathrm{P}>0.05)$ and lemongrass extract. 
Evaluation of antimicrobial activity of Lemongrass flavoured paneer

The antimicrobial activity of the various lemongrass added samples was evaluated against species of E.coli, Staph. aureus and Candida albicans and the results tabulated in Table 4. The experimental samples added with lemongrass did not show any significant ( $\mathrm{p} \leq 0.05$ ) inhibition activity against any of the species tested (E.coli, Staph. aureus and Candida. albicans), when compared with the lemongrass oil used as Standard Reference, which exhibited high antimicrobial activity against the same species under consideration, with a zone of inhibition of 17.00, 90.00 and
$29.33 \mathrm{~mm}$ for E. coli, Staph. aureus and Candida albicans, respectively. The fact that the pure lemongrass oil has showed inhibition is evident from literature (Morris et al., 1979) and amply demonstrated by the present experiment. Besides the bioactive components (phenols) present in the oil, the $\mathrm{pH}$ of the extract ( $\mathrm{pH}$ 3-5) could also have been responsible for the inhibition. However, the low concentration of lemongrass oil $\left(10^{1}-\right.$ $10^{3}$ ) added to the paneer so as not to diminish the organoleptic appeal along with the acidic $\mathrm{pH}$ of the paneer might have contributed to whatever little effect observed against the bacteria and fungi.

Table.1 Effect of method of incorporation of lemongrass on the sensory acceptance of paneer

\begin{tabular}{|l|c|c|c|c|}
\hline Sample & $\begin{array}{c}\text { Colour and } \\
\text { appearance }\end{array}$ & Flavour & $\begin{array}{c}\text { Body and } \\
\text { texture }\end{array}$ & $\begin{array}{c}\text { Overall } \\
\text { acceptability }\end{array}$ \\
\hline C & & & & \\
\hline T1 & $8.24 \pm 0.25^{\mathrm{bc}}$ & $8.20 \pm 0.20^{\mathrm{cd}}$ & $8.07 \pm 0.12^{\mathrm{a}}$ & $8.13 \pm 0.12^{\mathrm{cd}}$ \\
\hline T2 & $8.60 \pm 0.34^{\mathrm{c}}$ & $8.40 \pm 0.10^{\mathrm{d}}$ & $8.04 \pm 0.16^{\mathrm{a}}$ & $8.37 \pm 0.24^{\mathrm{d}}$ \\
\hline T3 & $7.86 \pm 0.32 \mathrm{a}^{\mathrm{b}}$ & $7.67 \pm 0.15^{\mathrm{bc}}$ & $7.97 \pm 0.18^{\mathrm{a}}$ & $7.83 \pm 0.11^{\mathrm{bc}}$ \\
\hline T4 & $7.53 \pm 0.50^{\mathrm{a}}$ & $7.29 \pm 0.25^{\mathrm{ab}}$ & $7.94 \pm 0.12^{\mathrm{a}}$ & $7.46 \pm 0.25^{\mathrm{ab}}$ \\
\hline
\end{tabular}

Note: Figures are mean \pm standard deviation of three replications. Values with different superscripts in a row are significantly different $(\mathrm{p} \leq 0.05)$

C: Control paneer; T1: Lemongrass extraction in milk (cut); T2: Lemongrass extraction in milk (crushed); T3:

Dipping in lemongrass extract; T4: Lemongrass oil in milk

Table.2 Radical scavenging activity of lemongrass added paneer samples against Std. Reference $-\mathrm{GAE}$

\begin{tabular}{|l|l|}
\hline Sample & \%RSA \\
\hline S & $72.62 \pm 0.49^{\mathrm{e}}$ \\
\hline T1 & $5.76 \pm 0.39^{\mathrm{bc}}$ \\
\hline T2 & $4.76 \pm 0.43^{\mathrm{b}}$ \\
\hline T3 & $3.53 \pm 0.47^{\mathrm{a}}$ \\
\hline T4 & $8.77 \pm 0.45^{\mathrm{d}}$ \\
\hline
\end{tabular}

Note: Figures are mean \pm standard deviation of three replications. Values with different superscripts in a row are significantly different $(\mathrm{p} \leq 0.05)$

S: Pure lemongrass extract; T1: Lemongrass extraction in milk (cut); T2: Lemongrass extraction in milk (crushed); T3: Dipping in lemongrass extract; T4: Lemongrass oil in milk

RSA - Radical Scavenging Activity (\% Inhibition) 
Table.3 Effect of addition of lemongrass on the total phenolic content of lemongrass added paneer samples against Standard

\begin{tabular}{|l|l|}
\hline Sample & GAE $(\mathbf{m g} / \mathbf{g})$ \\
\hline S & $1.5 \pm 0.05^{\mathrm{b}}$ \\
\hline T1 & $0.0046 \pm 0.0001^{\mathrm{a}}$ \\
\hline T2 & $0.0056 \pm 0.0003^{\mathrm{a}}$ \\
\hline T3 & $0.0040 \pm 0.0002^{\mathrm{a}}$ \\
\hline T4 & $0.0037 \pm 0.0002^{\mathrm{a}}$ \\
\hline
\end{tabular}

Note: Figures are mean \pm standard deviation of three replications. Values with different superscripts in a row are significantly different $(\mathrm{p} \leq 0.05)$

S: Pure lemongrass extract; T1: Lemongrass extraction in milk (cut); T2: Lemongrass extraction in milk (crushed); T3: Dipping in lemongrass extract; T4: Lemongrass oil in milk

GAE - Gallic Acid Equivalents

Table.4 Antimicrobial activity of paneer samples against E.coli, Staph. aureus and Candida albicans

\begin{tabular}{|l|l|l|l|l|}
\hline $\begin{array}{l}\text { Microorganism } \\
\text { tested }\end{array}$ & \multicolumn{4}{|c|}{ \% Inhibition } \\
\hline & $\begin{array}{l}\text { Std.Lemongrass } \\
\text { oil }(\mathrm{mm})\end{array}$ & $\begin{array}{l}\text { Paneer with } \\
\text { lemongrass oil }\end{array}$ & $\begin{array}{l}\text { Paneer with cut } \\
\text { leaf extract }\end{array}$ & $\begin{array}{l}\text { Paneer with crushed } \\
\text { leaf extract }\end{array}$ \\
\hline E.coli & $17.00 \pm 1.00$ & & No inhibition \\
\hline S.aureus & $90.00 \pm 0.00$ & & \\
\hline C.albicans & $29.33 \pm 0.36$ & & Slight inhibition \\
\hline
\end{tabular}

Fig.1a Gas-Chromatography analysis report of lemongrass added samples against Standard (Lemongrass oil) a) Paneer added with cut lemongrass leaf (4\% w/v) b) Paneer added with crushed lemongrass leaf $(2 \% \mathrm{w} / \mathrm{v}) \mathrm{c})$ Paneer added with lemongrass oil (0.02\%) and d) Pure lemongrass oil (Std. Reference

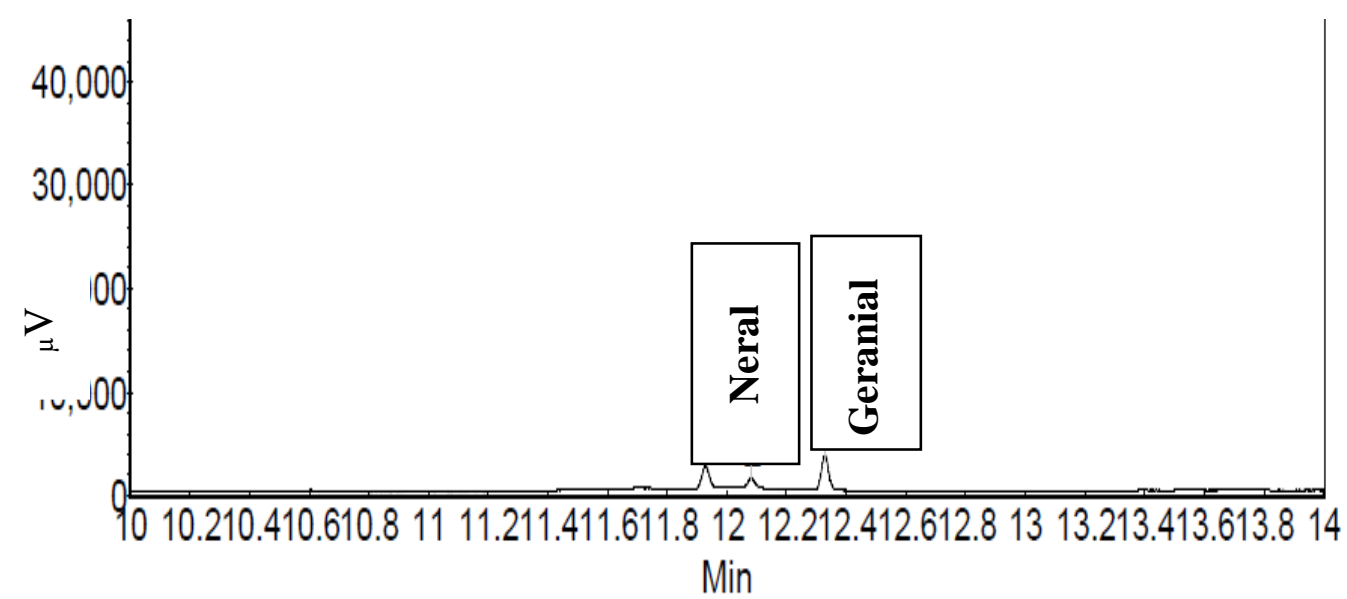

Neral: RT (min): 12.08; Area (\%): 2.64. Geranial: RT (min): 12.33; Area (\%): 6.81; RT-Retention Time Fig 1(a) 


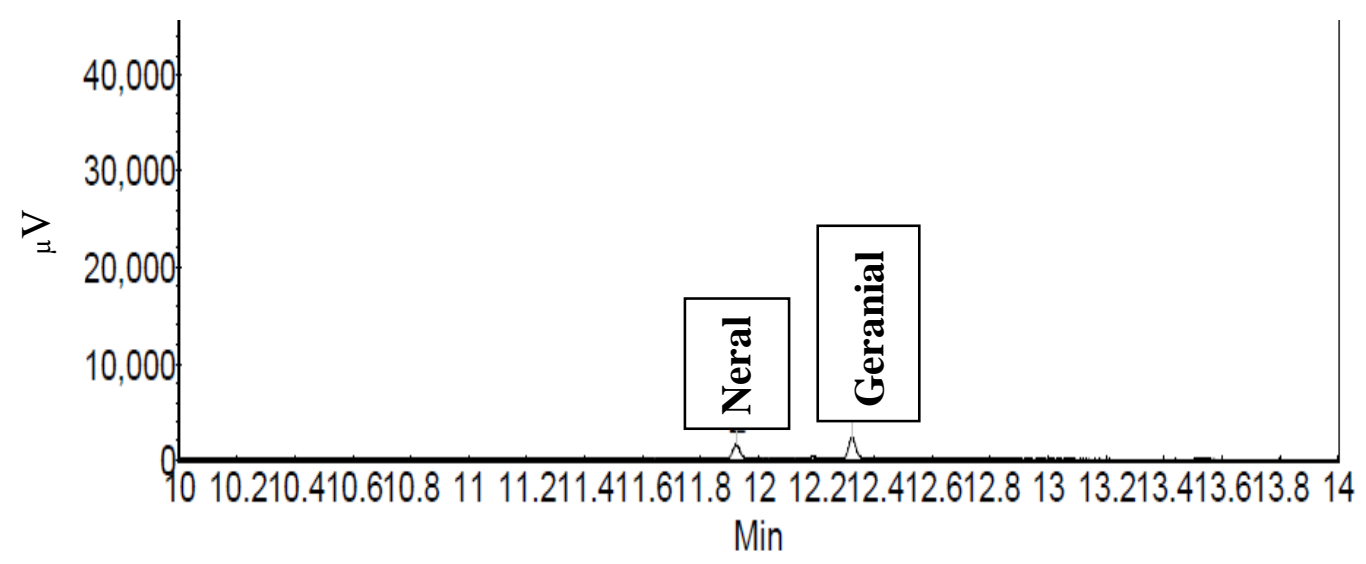

Neral: RT (min): 11.93; Area (\%): 0.14. Geranial: RT (min): 12.33; Area (\%): 0.26; RT-Retention Time Fig 1(b)

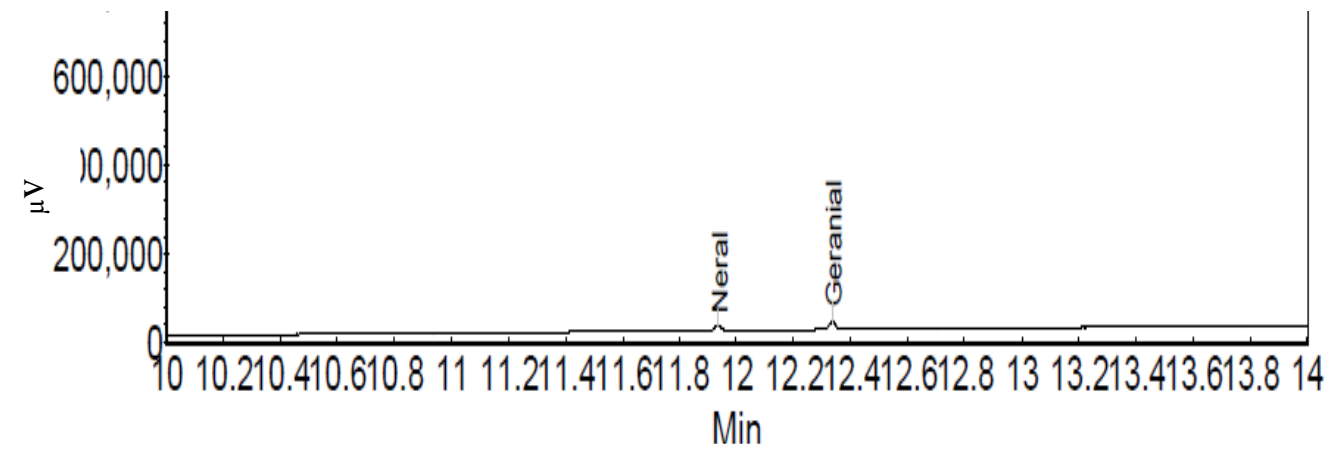

Neral: RT (min): 11.94; Area (\%): 8.96. Geranial: RT (min): 12.34; Area (\%): 13.37; RT-Retention Time Fig 1(c)

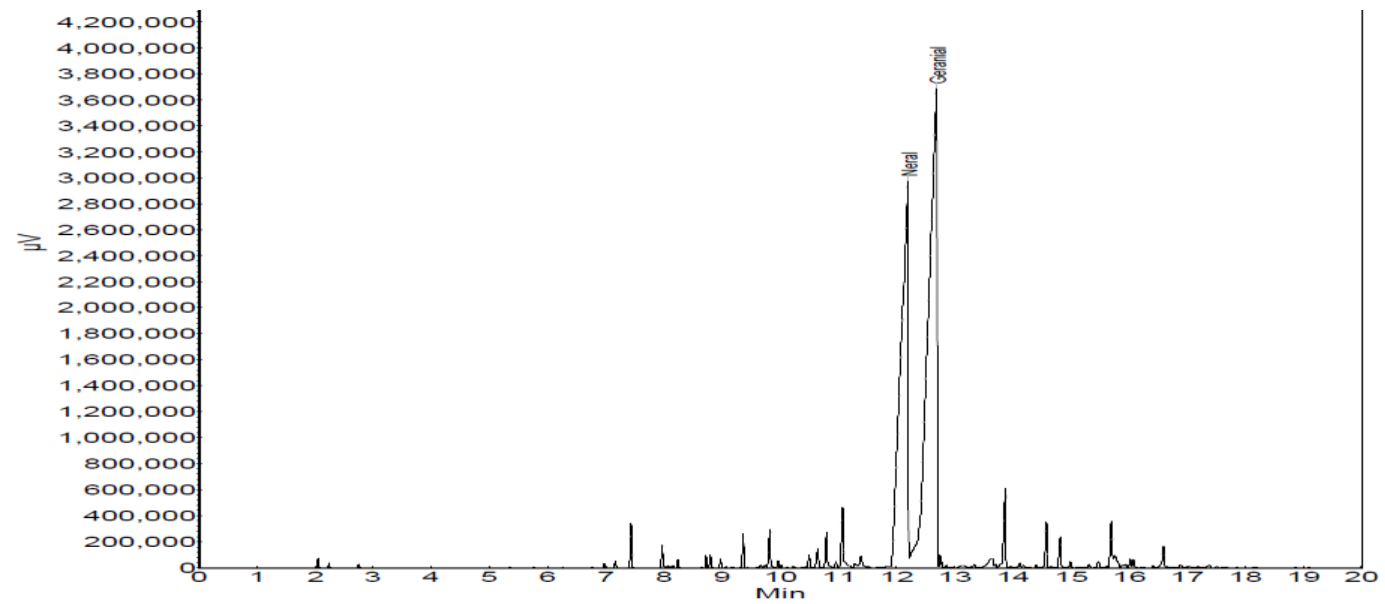

Neral: RT (min): 12.2; Area (\%): 32.73. Geranial: RT (min): 12.69; Area (\%): 50.07; RT-Retention Fig 1 (d) 


\section{Estimation of citral content of lemongrass containing paneer samples}

Lemongrass contains an aldehyde namely citral as its major component in 70-85\% concentration, which is responsible for the citrus aroma as well as the bioactivity. It is a mixture of two geometric isomers, geranial (citral A) and neral (citral B).

The citral content of the lemongrass added paneer samples, was analysed using GasChromatography and the results are shown in Figure 1. In the pure lemongrass oil (Std. Reference), neral and geranial corresponded to an area of $32.73 \%$ and $50.07 \%$ respectively. Both the isomers, neral and geranial, were eluted out, from all the experimental samples (paneer added with cut leaves, crushed leaves and lemongrass oil) when subjected to Gas-Chromatography, but with comparatively lesser area in the chromatogram.

The higher amount of citral was found in paneer added with lemongrass oil, while the lowest was obtained for paneer added with crushed leaves of lemongrass.

In conclusion, the present research has opened up possibilities of flavouring paneer with natural aroma. Paneer is a bland milk product and does not have any flavour of its own. The addition of herbs and spices to food and dairy products, due to their wide range of bioactivities along with enhancement of flavour and improved shelf life is increasingly being pursued. Being natural, herbs and spices appeal to consumers with regard to the safety of synthetic additives. The results show that use of the natural antioxidants occurring in herbs used in the Indian diet, or their extracts, is a viable option for the food industry as long as the organoleptic characteristics of the food product are not altered.

\section{Acknowledgements}

The first author gratefully acknowledges the financial assistance received from NDRI, Karnal (Deemed University), India in the form of Institutional Fellowship for carrying out the present project as well as to the Horticulture Division, UAS (B), GKVK, Bangalore for the technical support.

\section{References}

Anirudda S, Hemen S, Sarma TC, Ebibeni N (2011) Screening of essential oil obtained from inflorescence of lemongrass [Cymbopogon flexosus (Nees ex Steud.) Wats accessions. Indian J Nat Prod Resour 2(2): 236241

Ben-Yehoshua S, Rodov V, Fang DQ, Kim JJ (1995) Preformed antifungal compounds of citrus fruit: effect of postharvest treatments with heat and growth regulators. J Agri Food Chem 43: $1062-1066$

Bhattacharya DC, Mathur ON, Srinivasan M, Samilk D (1971) Studies on the method of production and shelf life of paneer (cooking type of acid coagulated cottage cheese). J Food Sci Technol 8(9): 117-120

Burger WC, Qureshi AA, E Charles (1986) Methods for lowering of blood cholesterol levels E; US Patent 1986: 4603142.

Carlson LHC, Machado RAF, Spricigo CB, Pereira LK, Bolzan A (2001) Extraction of lemongrass essential oil with dense carbon dioxide. J Supercrit Fluids 21: 33-39.

Conner DE, Beuchat LR (1984) Effects of essential oils from plants on growth of food spoilage yeasts. J Food Sci49: 429-434.

Deepa Garg, Aditya Muley, Nishtha Khare, Thankamani Marar

(2012) 
Comparative analysis of phytochemical profile and antioxidant activity of some Indian culinary herbs. Res J Pharm Biol Chem Sci., 3(3): 845-854

Dube K, Rao G, Sankara TS (1984) Antibacterial effect of some Indian essential oils. J Pet/ChemEng15 (1): 13-14

Elson CE, Underbakve GL (1989) Impact of lemon grass oil an essential oil on serum cholesterol. Lipiod 24(8): 677-9

Farag RS, Daw ZY, Abo Raya SH (1989) Influence of some spice essential oils on Aspergillus parasiticus growth and production of aflotoxins in a synthetic medium. J Food Sci54: 74-76

Fenwick GR, Lutomski L, Nieman C (1990) Licorice Glycyrrhiza global. Composition, uses and analyses. Journal of Food Science, 54(1): 74-76

Garcia R, Alves E, Santos M, ViegasAquije G, Fernandes A, Dos Santos R, Ventura J, Fernandes P (2008) Antimicrobial activity and potential use of monoterpenes as tropical fruits preservatives. Braz J Microbiol., 39: $163-168$

Hasim S, Falah RD, Ayunda, DNFaridah (2015) Potential of lemongrass leaves extract (Cymbopogon citrates) as prevention for oil oxidation. J Chem Pharm Res 7(10): 55-60

Ibrahim D (1992) Antimicrobial activity of the essential oil of the local serai, Cymbopogon citratus. J Biosci 3 (1-2): $87-90$

Isam SH, Mohd N (2009) Study the antimicrobial activity of Lemon grass leaf extracts, Iraq J Market Res Consumer Protection 1(2): 198-211

Jagannath D.A. (2012) Efficacy of herbal preservatives to enhance shelf life of paneer. Ph.D Thesis submitted to Mahatma Phule Krishi Vidyapeeth, Maharashtra (India).
Jiang S (1993) Pesticides made from plants. CN Pat 1,104, 85291993.

Josper C, Liguari ML (1958) Thein vitro Antifungal activity of essential oils. J Am Pharm Assoc 47(4): 250-257.

Kanawjia SK, Roy SK, Singh S (1990) Paneer technology and its diversification. Indian Dairyman 42: 390-393.

Leite JR, Seabra ML, Maluf E (1986) Pharmacology of lemongrass (Cymbopogon citratus Stapf) III. Assessment of eventual toxic, hypnotic and anxiolytic effects on humans. J Ethnopharmacol 17(1): 75-83

Lutterodt GD, Ismail A, Basheer R.H, Baharudin HM (1999) Antimicrobial effects of Psidium guajava extracts as one mechanism of its antidiarrhoeal action. Malays J Med Sci6(2): 17-20

Morris JA, Khetry A, Seitz EW(1979) Antimicrobial activity of Aroma chemicals and essential oils. J Am oil Chem Society 56(5): 595-603

Ojo OO, Kabutu F, Belo M, Babayo U(2006) Inhibition of paracetamol-induced oxidative stress in rats by extracts of lemongrass (Cymbopogon citratus) and green tea (Camellia sinensis) in rats. Afr J Biotech 5: 1227-1232

Onawunmi GO, Yisak W, Ogunlana EO (1984) Antibacterial constituents in the essential oil of Cymbopogan citratus (DC). J Ethnopharmacol., 12(3): 27986

OnawunmiGO, Ogunlana EO (1985) Effect of lemon grass oil on the cell and spheroplasts of E.coli. NCTC 9001. Microbios Letters, 28(110): 63-8

Rao BSS, Shanbhoge R, Rao BN, Adiga SK, Upadhya D, Aithal BK, Kumar MRS (2009) Alcoholic extract of Cymbopogon citrates against radiation induced DNA damage on V79 cells and free radical scavenging ability 
against radicals generated in vitro. Hum Exp Toxicol 28 (4):195-202.

Rao BG, Narasimh V (1971) Chemical examination of the Eugenia bracteata. Indian Perfume 14(1): 4-10.

Rios JL, Recio MC (2005) Medicinal plants and antimicrobial activity. J Ethnopharmacol. 100: 80-84

Sangwan NK, Verma KK, Verma BS, Malik MS, Dhindsa KS (1985) Nematocidal activity of essential oils of Cymbopogongrasses. Nematologia, 31(1): 93-9.

Schaneberg BT, Khan IA (2002) Comparison of extraction methods for marker compounds in the essential oil of lemongrass by GC. J Agric Food Chem., 50: 1345-1349

Shimada K, Fujikawa K, Yahara K, Nakamura T (1992) Antioxidative properties of xanthan on the autoxidation of soybean oil in cyclodextrin emulsion. J Agri Food Chem., 40: 945-948.

Silva CdeB, Guterres SS, Weisheimer V, Schapoval EE (2008) Antifungal activity of the lemongrass oil and citral against Candida spp. Braz J Infect Dis., 12(1): 63-66.
Singh RP, Jain DA (2011) Evaluation of antimicrobial activity of volatile oil and total curcuminoids extracted from turmeric. Int J Chem Tech Res., 3(3): 1172-1178.

Singleton VL, Orthofer R, Lamuela-Raventos RM (1999) Analysis of total phenols and oxidization substrates and antioxidants by means of FolinCiocalteu reagent. Methods Enzymol., 299: 152-177.

Vazquez-Briones MC, LR Hernandez, JA Guerrero-Beltran (2015) Physicochemical and Antioxidant Properties of Cymbopogon citratus Essential Oil. J Food Res 4(3): 36-45.

Villalobos MC (2010) Antioxidant Activity and Citral Content of Different Tea Preparations of the Above-Ground Parts of Lemongrass. Paper Presented in the 11th CPU Research Symposium. Central Philippine UnivRes Newsletter 9(1): 9-10.

Walker JRK (1994) Antimicrobial compounds in food plants. In "Natural antimicrobial systems and food preservation" (Eds. Dillon, V.M. and Board, R.G.). Wallingford: CAB International, pp. 181-204.

\section{How to cite this article:}

Krupa Joseph, K. Jayaraj Rao and Vasundhara, M. 2019. Bioactivity Analysis and Citral Content Estimation of Value Added Paneer Incorporated with Lemongrass Extract and Lemongrass Oil. Int.J.Curr.Microbiol.App.Sci. 8(06): 195-206.

doi: https://doi.org/10.20546/ijcmas.2019.806.024 